\title{
Analisis Antibodi Ireguler pada Reaksi Inkompatibel Darah Transfusi
}

\section{Irna Diyana Kartika K ${ }^{*}$, Hilma Yuniar Thamrin², Rachmawati Muhidin², Mansyur Arif ${ }^{2}$, Ibrahim Abdul Samad ${ }^{2}$ \\ ${ }^{1}$ Departement Patologi Klinik, Fakultas Kedokteran, Universitas Muslim Indonesia, Makassar, Indonesia \\ ${ }^{2}$ Departement Patologi Klinik, Fakultas Kedokteran, Universitas Hasanuddin, Makassar, Indonesia \\ *Corresponding Author. E-mail: irnadiyana@gmail.com, Mobile number: +62 8134-2641-642}

\begin{abstract}
ABSTRAK
Latar belakang: Terjadi kasus inkompatibilitas karena pemberian darah yang inkompatibel dapat disebabkan oleh dua hal, yang pertama akibat ketidakcocokan golongan darah saat melakukan transfusi sehingga terjadi reaksi hemolisis intravaskular akut dan juga dapat disebabkan oleh reaksi imunitas antara antigen dan antibodi karena adanya golongan darah lain atau antibodi ireguler. Penelitian ini bertujuan untuk menganalisis antibodi ireguler pada hasil inkompatibilitas darah transfusi uji silang serasi darah transfusi.

Metode: Penelitian ini merupakan penelitian observasional dengan menggunakan metode cross sectional. Sampel penelitian sebanyak 70 sampel inkompatibel uji silang serasi yang ditemukan di Unit Bank Darah RSUP Dr. Wahidin Sudirohusodo Makassar dan Unit Donor Darah PMI Makassar. Dilakukan pemeriksaan golongan darah dan uji silang serasi jika sampel yang telah di lakukan uji silang serasi dan hasilnya terjadi reaksi inkompatibel golongan darah maka sampel tersebut diambil kemudian di lanjutkan ke Direct antiglobulin test. Sampel yang Direct antiglobulin test positif dilanjutkan dengan pemeriksaan monospesifik yaitu tes IgG dan C3d. Analisis data menggunakan Metode analitik, yaitu dengan uji Chi Square untuk menilai variabel yang berhubungan dengan antibodi ireguler.

Hasil: Penelitian menunjukkan bahwa, dari 70 sampel yang mengalami reaksi inkompatibilitas ternyata hanya 7 sampel yang positif memiliki antibodi ireguler, di antaranya Anti E 3 (4,29\%), anti CDEd 1 (1,42\%), dari ketujuh sampel yang positif terdapat $2(2,86 \%)$ sampel yang positif semua pada sebelas sel panel tersebut dan terdapat 1 $(1,42 \%)$ sampel yang positif pada sel panel kecil (sel 1 dan sel 2) untuk skrining antibodi.

Kesimpulan: Kejadian inkompatibel golongan darah sebagian besar bukan karena adanya antibodi ireguler, hanya sekitar $10 \%$ inkompatibel akibat antibodi ireguler terjadi maka skrining antibodi ireguler belum menjadi urgensi di setiap Unit pelayanan Transfusi darah maupun di unit Bank darah Rumah sakit.
\end{abstract}

Kata Kunci: Antibodi ireguler; transfusi darah; inkompatibilitas darah transfusi

Article history:

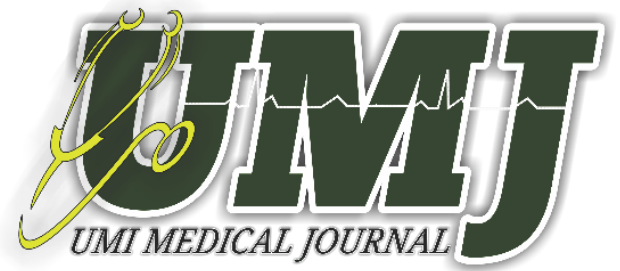

Received: 01 Mei 2020

Accepted: 23 Juni 2020

Published: 28 Desember2020

Published by :

Fakultas Kedokteran

Universitas Muslim Indonesia

Phone:

+6282293330002

\section{Address:}

Jl. Urip Sumoharjo Km. 5 (Kampus II UMI)

Makassar, Sulawesi Selatan.

Email:

medicaljournal@umi.ac.id 


\begin{abstract}
ABTRACT
Background: There are cases of incompatibility due to incompatible blood administration which can be caused by two things, the first is due to the incompatibility of blood groups during transfusion resulting in acute intravascular hemolysis reactions and can also be caused by immune reactions between antigens and antibodies due to the presence of other blood groups or antibodies. irregular. This study aims to analyze irregular antibodies on the results of blood incompatibilities in cross-test transfusions.

Methods: This study is an observational study using cross sectional method. The research sample was 70 incompatible cross-test matching samples found in the Blood Bank Unit of Dr. Wahidin Sudirohusodo Makassar and PMI Makassar Blood Donation Unit. Examination of blood type and cross-match is carried out if the sample that has been cross-tested is matched and the results are an incompatible reaction of blood groups then the sample is taken then proceed to the Direct antiglobulin test Samples with a positive Direct antiglobulin test were followed by monospecific tests, namely the $\mathrm{IgG}$ and $\mathrm{C} 3 \mathrm{~d}$ tests. Data analysis used analytical methods, namely by using the Chi Square test to assess variables associated with irregular antibodies.

Results: The study showed that, out of 70 samples that experienced incompatibility reactions, only 7 samples were positive for irregular antibodies, including Anti E 3 (4.29\%), anti CDEd 1 (1.42\%), of the seven positive samples. There were $2(2.86 \%)$ positive samples in all of the eleven panel cells and $1(1.42 \%)$ samples were positive in small panel cells (cell 1 and cell 2 ) for antibody screening.

Conclusion: Most blood group incompatibilities are not due to the presence of irregular antibodies, only about $10 \%$ incompatibilities due to irregular antibodies occur, so irregular antibody screening has not become an urgency in every blood transfusion service unit or in hospital blood bank units.
\end{abstract}

Keywords: Blood transfusion; irregular antibodies; incompatible blood transfusion

\title{
PENDAHULUAN
}

Penemuan golongan darah Landsteiner pada awal 1900-an didasarkan pada pengamatan bahwa sel darah merah beberapa individu menggumpal ketika bercampur dengan plasma dari individu lain. Klasifikasinya tentang golongan darah ABO dan penelitian selanjutnya oleh orang lain menegaskan bahwa antibodi dan antigen merupakan karakteristik yang diwariskan. Pada pertengahan 1940-an, tes antiglobulin dikembangkan, yang memungkinkan deteksi antibodi non-agglutinating, dan penyelidikan genetik biokimia dilakukan dilakukan, yang menetapkan bahwa spesifisitas antigen ditentukan oleh struktur oligosakarida. Secara umum ada yang bergolongan darah A, B, AB dan O. Penetapan golongan darah didasarkan pada ada tidaknya antigen sel darah merah A dan B yang menjadi standar pemeriksaan sebelum transfusi darah.(1,2)

Adanya sifat multiantigenik dari donor ke resipien bisa menyebabkan terjadi kasus inkompatibilitas. Transfusi darah yang tidak sesuai sering menyebabkan reaksi hemolitik akut yang diikuti oleh disseminated intravascular coagulation (DIC) and acute kidney injury (AKI).(3) Dalam sebuah laporan oleh Kim et al. (2008), gejala terjadi pada 64\% pasien yang ditransfusikan dengan $A B O$ incompatible blood transfusion $\geq 50 \mathrm{~mL}$, dan angka kematian adalah 17\%, sedangkan laporan dari Ira et al. (2014) di Makassar, Indonesia khususnya di RSUP Wahidin Sudirohusodo pada tahun 2013-2014 terdapat 213 kasus inkompatibilitas darah baik yang mayor,minor dan atau keduanya seperti yang dilaporkan oleh.(4,5) Untuk memastikan bahwa transfusi darah tidak akan menimbulkan reaksi pada 
resipien maka sebelum pemberian transfusi darah kepada resipien, perlu dilakukan beberapa pemeriksaan laboratorium terhadap darah donor dan darah resipien. Secara praktis pemeriksaan yang rutin dilakukan sebelum transfusi darah adalah pemeriksaan terhadap sel darah merah saja, yaitu terdiri dari pemeriksaan golongan darah $\mathrm{A}, \mathrm{B}, \mathrm{AB}, \mathrm{O}$ dan rhesus, serta uji silang serasi.(1)

Pemberian darah yang inkompatibel dapat disebabkan oleh dua hal, yang pertama akibat ketidakcocokan golongan darah saat melakukan transfusi sehingga terjadi reaksi hemolisis intravaskular akut dan yang kedua dapat disebabkan oleh reaksi imunitas antara antigen dan antibodi karena adanya golongan darah lain atau antibodi ireguler dimana bila tidak diketahui bisa menyebabkan reaksi transfusi seperti demam, reaksi alergi, reaksi hemolitik, reaksi anafilaktik, infeksi dan bahkan cedera paru-paru akibat transfusi(TRAIL).(6,7)

Pemeriksaan uji silang serasi hanya dapat menentukan adanya antibodi golongan darah A, B, dan O serta rhesus, sedangkan untuk menentukan antibodi golongan darah lain tersebut secara spesifik maka perlu dilanjutkan dengan skrining dan identifikasi antibodi ireguler. Berdasarkan hal-hal tersebut diatas maka perlu dilakukan analisis penyebab atau yang melandasi terjadinya kejadian inkompatibilitas antara darah donor dan darah pasien yang dihubungankan dengan antibodi ireguler. Tujuan penelitian ini untuk menganalisis antibodi ireguler pada hasil inkompatibilitas darah transfusi uji silang serasi darah transfusi.

\section{METODE}

Penelitian ini dilakukan di Unit Bank Darah RSUP Dr. Wahidin Sudirohusodo Makassar. Jenis penelitian yang digunakan merupakan penelitian cross sectional. Populasi penelitian adalah semua sampel yang dilakukan uji silang serasi di Unit bank Bank Darah RSUP Dr. Wahidin Sudirohusodo Makassar dan Unit Donor Darah PMI makassar. Sampel penelitian sebanyak 70 sampel inkompatibel uji silang serasi yang ditemukan di Unit Bank Darah RSUP Dr. Wahidin Sudirohusodo Makassar dan Unit Donor Darah PMI Makassar. Sampel darah diambil melalui vena mediana cubiti yang kemudian dimasukkan dalam kantong darah dan tabung vakutainer dan dilakukan pemeriksaan golongan darah dan uji silang serasi jika sampel yang telah di lakukan uji silang serasi dan hasilnya terjadi reaksi inkompatibel golongan darah maka sampel tersebut diambil kemudian di lanjutkan ke Direct antiglobulin test. Sampel yang Direct antiglobulin test positif dilanjutkan dengan pemeriksaan monospesifik yaitu tes IgG dan C3d. Sampel yang positif IgG atau C3d maupun kombinasi keduanya dilanjutkan ke tes S1 dan S2 yang merupakan tes skrining antibodi ireguler bila sampel positif pada sel panel S1 dan S2 maka akan di lanjutkan ke sel panel besar untuk menentukan jenis antibodi ireguler yang terdapat dalam sampel. Analisis data menggunakan Metode analitik, yaitu dengan uji Chi Square untuk menilai variabel yang berhubungan dengan antibodi ireguler. Hasil uji dianggap signifikan jika nilai $\mathrm{p}<0.05$. 


\section{HASIL}

Penelitian dilakukan selama periode Januari 2015 sampai dengan Maret 2015 di RSUP Dr. Wahidin Sudirohusodo (RSWS) dan UDD PMI Makassar. Selama periode tersebut diperoleh 70 sampel yang memenuhi kriteria penelitian, mengikuti penelitian dengan sukarela dan menandatangani pernyataan persetujuan. Terdiri atas laki-laki 38 orang $(54,28 \%)$ dan perempuan 32 orang $(45,71 \%)$. Rentang umur dibagi menjadi umur $<17$ tahun 5 orang $(7,14 \%)$ dan umur $\geq 17$ tahun 65 orang $(92,85 \%)$.

Diagnosa dikelompokkan berdasarkan diagnosa dibagi menjadi kelompok neoplasma 13 orang (18,57\%), kelompok infeksi sebanyak 15 orang (21,43\%), kelompok endokrin metabolik sebanyak 27 orang $(38,57 \%)$, hemodialisa 2 orang $(10,00 \%)$, kehamilan tidak ada riwayat transfusi berulang 3(4,29\%), dan kelompok lain-lain 5 orang (7,14\%). Golongan darah dibagi menjadi golongan darah A sebanyak 20 (28,6\%), B 19 orang (27,1\%), AB 3 orang (4,3\%), dan golongan darah O 28 orang (40,0\%). Semua rhesus didapatkan rhesus positif (100\%) tabel 1.

Tabel 1. Karakteristik subyek penelitian

\begin{tabular}{lc}
\hline Variabel (n=70) & $\mathbf{n}(\boldsymbol{\%})$ \\
\hline Umur: & \\
< 17 tahun & $5(7,14)$ \\
$\geq 17$ tahun & $65(92,85)$ \\
\hline Jenis Kelamin: & \\
Laki-laki & $38(54,28)$ \\
Perempuan & $32(45,71)$ \\
\hline Kelompok diagnosis: & \\
Infeksi & $15(21,43)$ \\
Neoplasma & $13(18,57)$ \\
Endokrin metabolik & $27(38,57)$ \\
Hemodialisa & $7(10.00)$ \\
Kehamilan & $0(0,0)$ \\
Riwayat transfusi & $3(4,29)$ \\
Berulang dan & $5(7,14)$ \\
lain-lain & \\
A & \\
B & $20(28,6)$ \\
AB & $19(27,1)$ \\
O & $3(4,3)$ \\
Rhesus: & $28(40,00$ \\
Positif & $70(100)$ \\
Negatif & $0(0,0)$ \\
\hline Sungan Dah: &
\end{tabular}

Sumber : data primer 
Dari 70 kasus inkompatibel, penelitian ini hasil positif pada uji antiglobulin langsung (DAT=Direct Antiglobulin Test) sebanyak 70 sampel(100\%), hasil positip terhadap IgG pada DAT ditemukan sebanyak 46 kasus (65,71\%), hasil positip terhadap komplemen C3d pada DAT sebanyak 0 sampel $(0,0 \%)$, sedangkan hasil positip terhadap kombinasi IgG dan C3d pada DAT sebanyak 24 sampel(34,29\%) tabel 2.

\begin{tabular}{|c|c|c|c|}
\hline & IgG + & $\mathrm{CD3}+$ & IgG dan C3D + \\
\hline $\mathrm{N}(\%)$ & $\begin{array}{c}46 \\
(65,71 \%)\end{array}$ & & $24(34,29 \%)$ \\
\hline TOTAL & $\begin{array}{c}46 \\
(65,71 \%)\end{array}$ & - & $24(34,29 \%)$ \\
\hline
\end{tabular}

Dari 70 sampel yang mengalami reaksi inkompatibilitas ternyata hanya 7 sampel yang positif memiliki antibodi ireguler, di antaranya Anti E 3 (4,29\%), anti CDEd 1 (1,42\%), dari ketujuh sampel yang positif terdapat $2(2,86 \%)$ sampel yang positif semua pada sebelas sel panel tersebut dan terdapat $1(1,42 \%)$ sampel yang positif pada sel panel kecil (sel 1 dan sel 2) untuk skrining antibodi, namun setelah dilanjutkan kesebelas sel panel untuk identifikasi antibodi tidak dapat ditentukan jenis antibodi apa yang terkandung di dalamnya tabel 3 .

Tabel 3. Hasil pemeriksaan DAT dan identifikasi antibodi ireguler

\begin{tabular}{cccc}
\hline & Penyebab & Jumlah & $\%$ \\
\hline Inkompatibel & DAT IgG & 46 & 65,71 \\
$\mathrm{n}=70$ & DAT IgG + C3d & 24 & 34,29 \\
& DAT C3d & 0 & 0,0 \\
Antibodi ireguler & Anti E & 3 & 4,29 \\
$\mathrm{n}=7$ & Anti CDEd & 1 & 1,42 \\
& Semua jenis Antibodi dalam Panel & 2 & 2,86 \\
& Tidak terdapat dalam 11 panel & 1 & 1,42
\end{tabular}

Analisis DAT Positif yang dihubungkan dengan IgG,C3d dan antibodi ireguler

\section{PEMBAHASAN}

Dari hasil penelitian diketahui bahwa penyebab terbesar inkompatibilitas pada uji silang serasi adalah uji antiglobulin langsung (DAT=Direct Antiglobulin Test) yang positif 70 (100\%). Hasil positif pada DAT dapat memprediksi $83 \%$ anemia hemolitik autoimun dan 1,4\% kasus tanpa anemia hemolitik.(8) Serupa dengan hasil Ria Syafirti et al. (2003) menemukan 92,90\% dari kasus inkompaibilitas disebabkan oleh adanya uji antiglobulin langsung (DAT=direct Antiglobulin Test), berbeda dengan penemuan Ratna 
Ningrum et al. (2018) menemukan adanya antibodi ireguler dengan menggunakan uji antiglobulin tidak langsung (IAT= Indirect Antiglobulin Test).(5,9) Dengan demikian, ketika ditemukan kasus inkompatibilitas pada uji silang serasi, maka pemeriksaan yang pertama kali harus dilakukan adalah pemeriksaan uji antiglobulin langsung maupun tidak langsung. Uji antiglobulin langsung maupun tidak langsung adalah salah satu metode yang digunakan untuk mendemonstrasikan adanya antibodi atau komplement yang terikat pada membran sel darah merah dengan menggunakan anti-human globulin yang nantinya akan bereaksi membentuk agglutinasi. Tes IAT untuk antibodi yang berada di dalam plasma pasien sedangkan DAT untuk antibodi atau komponen yang terikat langsung pada sel darah merah pasien.(10)

Hasil penelitian ini menunjukkan bahwa kejadian inkompatibel akibat antibodi ireguler pada pasienpasien di RSUP Wahidin Sudirohusodo masih sangat kecil sehingga pertimbangan untuk menjadikan skrining antibodi ireguler tersebut belum menjadi urgensi di setiap Unit pelayanan transfusi darah maupun di unit Bank darah rumah sakit. Dari ketujuh sampel yang positif terdapat 2 sampel yang positif terhadap 11 panel antibodi ireguler yang ada. Kedua sampel ini diketahui dengan diagnosa ca.mammae. Berdasarkan hasil gradasi kepositifan pada ke sebelas sel panel yang ada, kedua sampel tersebut memiliki gradasi positif yang sama yaitu positif 2, hasil tersebut menunjukkan bahwa sampel tersebut (dalam tubuh pasien) terdapat autoantibodi (antibodi ekstra) atau antibodi ireguler. Antibodi ireguler atau antibodi non spesifik tersebut bisa disebabkan karena proses keganasan (malignancy). Sedangkan 1 sampel yang tidak bisa ditentukan jenis antibodi iregulernya kemungkinan antibodi yang terdapat di dalam sampel merupakan antibodi yang non spesifik atau tidak termasuk ke dalam ke sebelas sel panel tersebut. $(11,12)$

\section{KESIMPULAN}

Kejadian inkompatibel golongan darah sebagian besar bukan karena adanya antibodi ireguler, diagnosis pasien yang menderita penyakit endokrin metabolik paling banyak yang mengalami inkompatibel golongan darah tetapi tidak positif memiliki antibodi ireguler. Kejadian inkompatibel akibat antibodi ireguler di RSUP Wahidin Sudirohusodo hanya sekitar 10\%. Sehingga pertimbangan untuk menjadikan skrining antibodi ireguler tersebut belum menjadi urgensi di setiap Unit pelayanan Transfusi darah maupun di unit Bank darah Rumah sakit. 


\section{DAFTAR PUSTAKA}

1. Mujahid A, Dickert FL. Blood group typing: From classical strategies to the application of synthetic antibodies generated by molecular imprinting. Sensors (Switzerland). 2016;16(1).

2. Ewald DR, Sumner SCJ. Blood type biochemistry and human disease. Wiley Interdiscip Rev Syst Biol Med. 2016;8(6):517-35.

3. Namikawa A, Shibuya Y, Ouchi H, Takahashi H, Furuto Y. A case of ABO-incompatible blood transfusion treated by plasma exchange therapy and continuous hemodiafiltration. CEN Case Reports [Internet]. 2018;7(1):114-20. Available from: http://dx.doi.org/10.1007/s13730-018-0307-4

4. Janatpour KA, Kalmin ND, Jensen HM, Holland P V. Clinical outcomes of ABO-incompatible RBC transfusions. Am J Clin Pathol. 2008;129(2):276-81.

5. Irawaty I, AM R, Arif M. Characteristics of crossmatch types in compatibility testing on diagnosis and blood types using gel method. Indones J Clin Pathol Med Lab. 2018;23(1):36.

6. Harvey G. Klein DJA. Mollison's Blood Transfusion in Clinical Medicine, 12th Edition. In Wiley Blackwell; 2014. p. 944.

7. Suddock JT, Crookston KP. Transfusion Reactions. In Treasure Island: StatPearls; 2020. Available from: https://www.ncbi.nlm.nih.gov/books/NBK482202/

8. Vandana Puri, Aruna Chhikara, Geetika Sharma, Shivali Sehgal and SS. Critical evaluation of donor direct antiglobulin test positivity: Implications in cross-matching and lessons learnt. Asian J Transfus Sci. 2019;13(1):70-2.

9. Ningrum NR, Ritchie NK, Syafitri R. Skrining Antibodi Dan Identifikasi Antibodi Pada Pasien Transfusi Di Laboratorium Rujukan Unit Transfusi Darah Pmi Dki Jakarta. Pros Pertem Ilm Nas Penelit dan Pengabdi Masy PINLITAMAS. 2018;1(1):589-96.

10. Parker V, Tormey CA. The direct antiglobulin test: Indications, interpretation, and pitfalls. Arch Pathol Lab Med. 2017;141(2):305-10.

11. Maitta RW, editor. Immunologic concepts in transfusion medicine. In Elsevier Health Sciences; 2019. p. 380.

12. Mitra R, Mishra N, Rath GP. Blood groups systems. Indian J Anaesth. 2014;58(5):524-8. 